\title{
Fallen from the Trail - A case study based on Banking Sector in Bangladesh
}

\author{
Md. Mushfiqur Rahman Anas ${ }^{1}$ \\ Ruhul Amin ${ }^{*}$ \\ ${ }^{1}$ Audit \& Assurance, Khan Akber \& Co., Chartered Accountants, Bangladesh \\ ${ }^{* 2}$ Department of MBA, North South University, Bangladesh \\ *(ruhulaminshuzon@gmail.com)
}

This journal is licensed under a Creative Commons Attribution-Noncommercial 4.0 International License (CC-BY-NC). Articles can be read and shared for noncommercial purposes under the following conditions:

- BY: Attribution must be given to the original source (Attribution)

- NC: Works may not be used for commercial purposes (Noncommercial)

This license lets others remix, tweak, and build upon your work non-commercially, and although their new works must also acknowledge you and be non-commercial, they don't have to license their derivative works on the same terms. License Deed Link: http://creativecommons.org/licenses/by-nc/4.0/

Legal Code Link: http://creativecommons.org/licenses/by-nc/4.0/legalcode

$A B C$ Research Alert uses the CC BY-NC to protect the author's work from misuse.

\section{Abstract}

The history of bank failures in many countries indicates that loss of public confidence in banks could be contagious and quickly lead to systemic banking crisis situations. The depositors might lose confidence in the Bank for such activities. Corporate Governance is concerned with holding the balance between economic and social goals and between individuals and communal goals. Banks can undertake all business operations as a result of public trust and faith in the stability and soundness of the banks in particular and the system in general.

The study was carried out to measure the financial crisis and Corporate Governance in the troubled banks in Bangladesh. The concerned bank was forced to pay off loans from the four banks with its securities - treasury bonds and bills - with the Bangladesh Bank. In Bangladesh, commercial banks need to keep the securities with the central bank to maintain its mandatory Statutory Liquidity Requirement (SLR). Currently, few banks have no securities to sustain SLR. A bank has to keep at least 19 percent of its depositors' money in the form of SLR and CRR with the central bank to protect the interest of the depositors.

\section{Keywords}

Financial Crisis, Banking, Depositors Trust, Monetary System, Corporate Governance, Central Bank Guidelines, Security, Liquidity, Systematic Risk

\section{INTRODUCTION}

Corporate Governance is apprehensive with holding the balance between social \& economic goal goals and between individuals and shared objectives. The organizational governance structure is there to push the proficient exercise of resources and evenly to entail liability for the stewardship of those resources. In recent years, corporate stakeholders across the globe have become more concerned than ever about the quality of corporate governance (CG) 
practices, and a series of recent corporate collapses in different parts of the world have contributed to their interested concern. Sound CG practices are the foundations upon which the trust of investors (stakeholders, banks, and nonbank financial institutions) and other stakeholders is built; whereas poor CG practices lower the confidence level of a company's stakeholder, especially that of investors as Sound corporate governance (CG) is a prerequisite to developing a well-functioning capital market, and it improves access to capital for both public and private entities. The low level of investor confidence, which serves as one of the impediments to increased investments, needs to be addressed for the future growth and development of the capital market of Bangladesh. Corporate Governance is the key to the global integrity of corporate institutions especially financial institutions and other sectors. Financial institutions have suffered a lot of deterioration in their asset portfolios, primarily due to distorted credit management and this has led to the crisis in the body and ultimately to the collapsing of Banks. A good corporate governance system helps a bank perform better complying all the rules and regulations. It makes the decisions makers more accountable to respective authorities.

\section{OBJECTIVE OF THE STUDY}

The foremost objective of this study is to evaluate the Effect of Corporate Governance in the commercial banks in Bangladesh. The subsequent objective is to find out what is the effect of these Banks in the Economy of Bangladesh banking sector.

\section{LIMITATIONS OF THE STUDY}

The core limitation of this study is that it cannot be shown all the performance of Corporate Governance \& Financial Crisis of the banks in Bangladesh. Other restrictions are:

a) The data related to Bank and other conventional financial institutions are inadequate.

b) There are very few data regarding Corporate Governance practices in Bangladesh available.

\section{LITERATURE REVIEW}

The word 'corporate governance' has become a catchphrase due to the Asian financial crisis in 1997-98, the behavior of the commercial sector affected entire economies, and deficiencies in $\mathrm{CG}$ endangered the stability of the global financial system. In general, CG deals with laws, procedures, practices and implicit rules that determine company's ability to take managerial decisions vis-à-vis its claimants - in particular, its shareholders, creditors, customers, the State, and employees. However, a somewhat broader definition would be to define CG as a set of mechanisms through which a single country or firms within a country operates when ownership is separated from management.

Therefore, corporate governance is the system by which companies directed and controlled. There is a global consensus about the objective of 'good' corporate governance: maximizing long-term shareholder value. Since shareholders are residual claimants, this goal follows from a premise that, in the well-performing capital and financial markets, whatever maximizes shareholder value must necessarily maximize corporate prosperity, and best satisfy the claims of creditors, employees, shareholders, and the State. 
Corporate governance, therefore, calls for three factors:

a) Presents of transparency in decision-making,

b) Accountability which follows from openness because responsibilities could be fixed easily for actions taken or not taken, and;

c) The liability is for the safeguarding the interests of the stakeholders and the investors in the organization

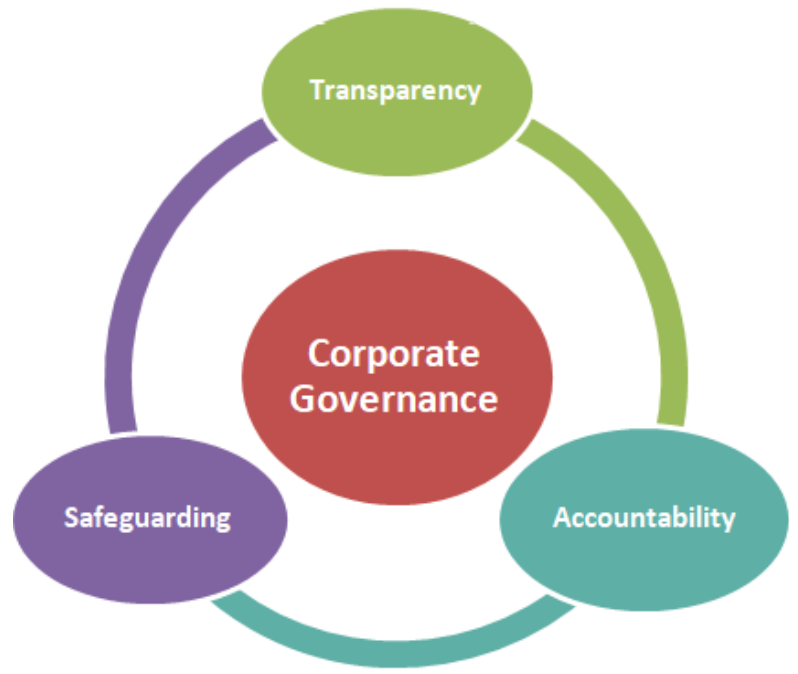

Figure 1: Three Factors of Corporate Governance

The Banking and financial sector is readily distinguishable from the others. A few distinguishing features stand out:

Unlike standard business entities which are funded mainly through shareholders' funds, banking business involves funds raised mainly through deposits. The business of raising public deposits places greater fiduciary responsibilities on the institution and its managers since depositors' funds need to safeguarded especially. Banks perform as financial intermediaries by lending and investing the resources mobilized and funding economic activities of others.

Banks are the agents of the payments system where they facilitate payments domestically and internationally, through various instruments such as bank accounts, fund transfers, credit cards, etc. Banks can undertake all such business operations as a result of public trust and faith in the stability and soundness of the banks in particular and the system in general.

The history of bank failures in many countries indicates that loss of public confidence in banks could be contagious and could quickly lead to systemic banking crisis situations. 


\section{Code of Corporate Governance for banks and financial institutions covers 8 principles. These are:}

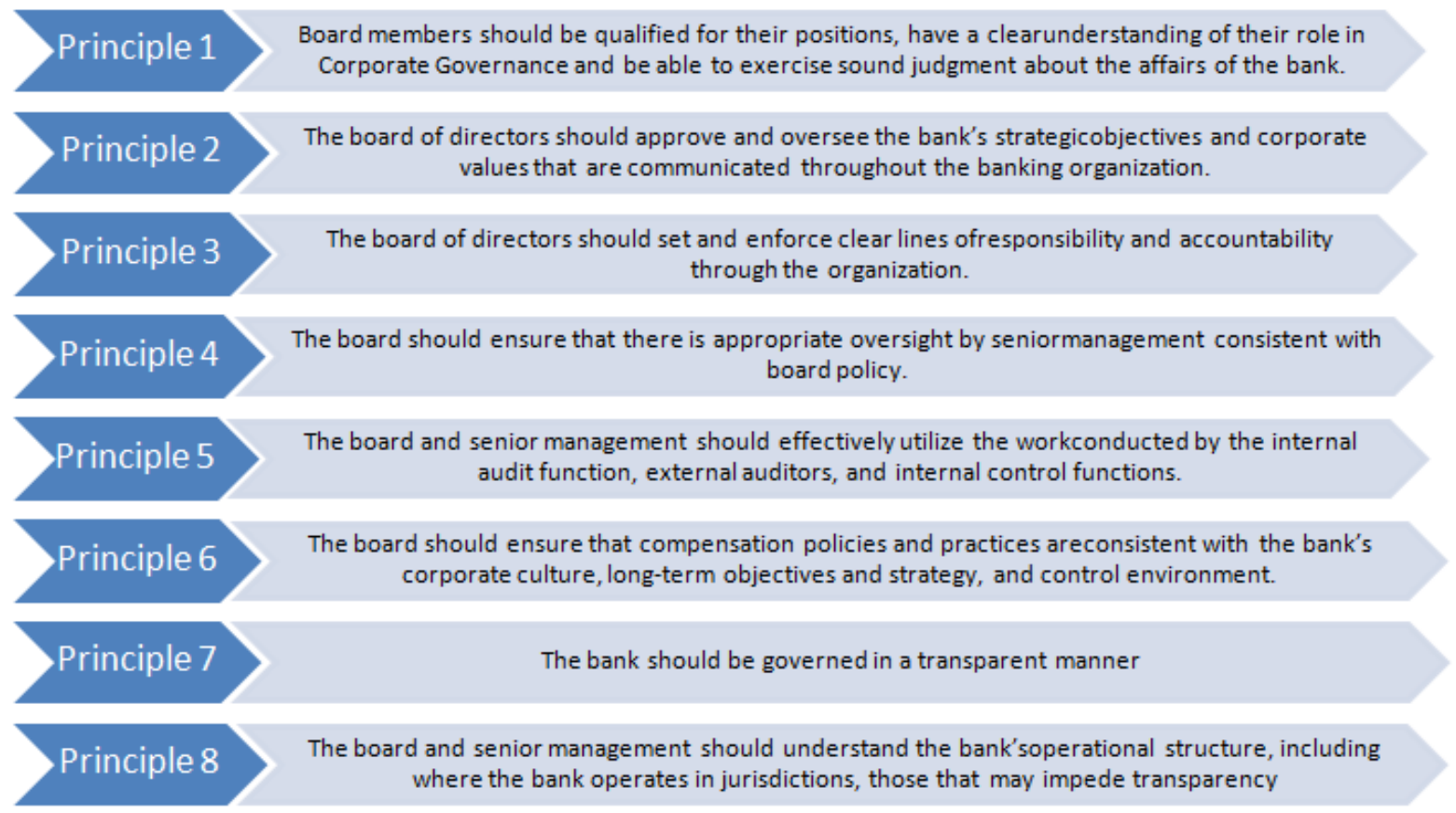

Figure 2: Eight Principle of Corporate Governance for banks and financial institutions.

From figure 2, we can see that eight principles suggested primarily for banks and financial institutions from Corporate Governance theory. The first policy indicates that the Board individuals ought to meet all requirements for their positions, have a reasonable comprehension of their part in Corporate Governance and have the capacity to practice sound judgment about the undertakings of the bank. The second principle deals with the top managerial staff ought to favor and administer the bank's key targets, and corporate esteems that are imparted all through the keeping money association.

The third Principle suggests the governing body should set and implement clear lines of obligation and responsibility through the association. The fourth Principle implies that the board ought to guarantee that there is the appropriate oversight by senior administration steady with board strategy.

The fifth Principle recommends that the board and senior administration have to adequately use the work led by the inward review work, outer evaluators, and inside control capacities. The sixth Principle implies that the board must guarantee that remuneration strategies and practices are predictable with the bank's corporate culture, long-haul targets and procedure, and control condition. The second last Principle suggests that the bank ought to represented in a straightforward and translucent way.

The last Principle recommends that the board and senior administration ought to comprehend the bank's operational structure, including where the bank works inwards, those that may hinder straightforwardness (i.e., "know-your-structure") 


\section{Effects of Corporate Governance in the Commercial Banks in Bangladesh:}

There are hundreds of example can be made of the proper practice of Corporate Governance in many banks which operates in Bangladesh. Most of the banks work with the satisfaction and closely monitored by the central bank of Bangladesh, also known as Bangladesh Bank. The central bank of Bangladesh is very strict and dedicated to practicing corporate governance in commercial banks. But few banks left behind and cannot follow the regulation as desired. For instance, A report of the Bank and Financial Institutions Division (BFID) shows concerns about the irregularities in Farmers Bank Ltd. The report termed the financial institute as 'risky' for the banking division of Bangladesh. It said that the troubled financial institution was taking loans with high-interest rates from depositors and other banks while it cannot pay back, creating 'systematic risk' for the entire financial sector of Bangladesh. The bank's depositors might lose confidence in it for these activities, warned by the BFID. It also said that the troubled financial institution was taking new loans which violating a ban by the central bank, adding that the bank had also admitted to the irregularities.

The cash-strapped troubled Bank failed to repay short-term interbank loans of about BDT 700 crore to four banks over two months, a growth that may further erode depositors' confidence in the scam-hit bank. The interbank lending market is where banks borrow from each other for a specific term, mostly for one week or less. Often, such loans are taken for a day. So the troubled bank was forced to pay off loans from the four banks with its securities, treasury bonds and bills with the Bangladesh Bank.

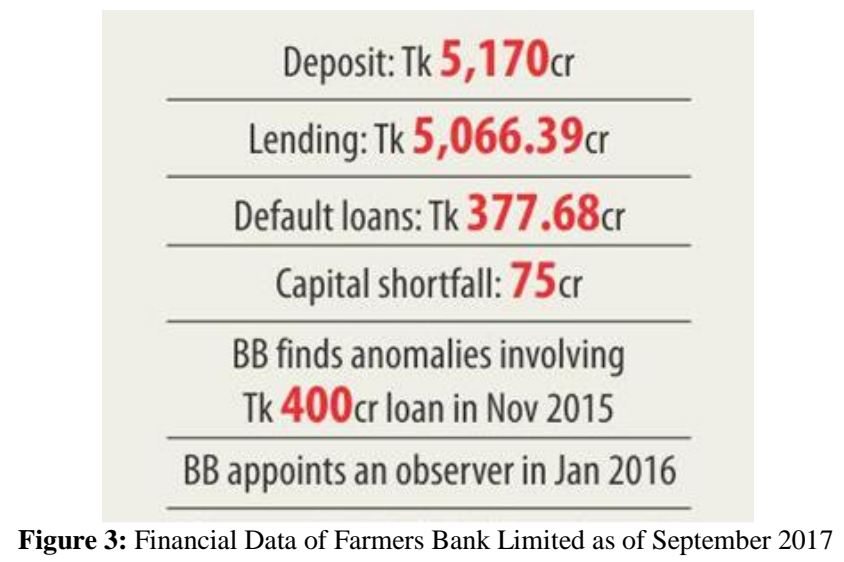

The troubled Bank had kept the securities with the central bank so that it can preserve its obligatory statutory Liquidity Requirement or (SLR). But now the bank has no guards to sustain SLR. A bank has to keep 19 percent of its depositors' money in the form of SLR and CRR (Cash Reserve Ratio) with the central bank to protect the interest of the depositors. The Bangladesh Bank (BB) has already announced a penalty of BDT 18.49 crore on the troubled Bank because of its failure to keep the CRR and SLR between October 2016 and September 2017. The bank took the short-term loans from state-run Sonali, Agrani and Janata banks and privately-owned NRB Global bank between November and December 2017 by way of the repo to meet its immediate liquidity demand. Sonali Bank alone gave over BDT 419 crore. The situation has turned so sorry that no bank now wants to lend money to the distressed Bank in the overnight call money market. 
Against this backdrop, the central bank has verbally instructed four state-owned commercial banks to provide Farmers Bank loans through the interbank call money, also called overnight money market, after private commercial banks refused to do so even at higher rates of return. According to the Bangladesh Bank (BB) data, the ailing bank is now receiving about BDT 150 crore from the state-owned banks every working day through the interbank call money market. And to take loans, Farmers Bank has to count 4.5 percent interest, higher than the average 3.8 percent in the market.

Contacted, former caretaker government adviser alleged, "The central bank should take over the Farmers Bank if it fails to pay back depositors' money." Once, the Oriental Bank (now ICB Islamic Bank) faced a crisis, and the central bank (BB) rescued it by appointing an administrator there.

Earlier in January 2016, the central bank (BB) appointed an observer at the troubled Bank after it found a gross violation of banking rules in sanctioning and disbursing loans and hiding defaulted loans amounting to around BDT 400 crore.

That was the first time the central bank appointed an observer for a new bank. Since launching the operation, this Bank could not follow the regulatory guidelines. The bank's financial base gradually weakened because of various irregularities at the directorial board and management level.

The financial base of the bank is getting weak due to its negligence in following regulatory and prudential rules and anomalies taken place at different stages of the Board of Directors and management after the inception of its banking activities. The Bangladesh Bank recently formed a standing committee headed by its Deputy Governor to look into FBL matters and aim to find out the actual cause of fall.

\section{CONCLUSION:}

The need for a competent financial sector is important to stimulate and support economic growth through efficient resource allocation. Good Corporate Governance (CG) practices are essential for the effectiveness, competitiveness, safety and soundness of financial institutions. Given the special nature of banking institutions, a broad view of Corporate Governance (CG) where regulation of banking activities is required to protect depositors. In developed economies, shield of depositors in a deregulated environment is typically provided by a system of prudential regulation, but in emerging economies, such protection is undermined by the lack of well-trained supervisors, inadequate disclosure requirements, the cost of raising banks capital and the presence of distributional cartels.

Corporate Governance (CG) of financial institutions, particularly banking sector, in Bangladesh is severely affected due to lack of proper training and management. Given the trend towards privatization of government-owned banks in Bangladesh, there is a need for the managers of such banks to be granted autonomy and be gradually introduced to the Corporate Governance (CG) practices of the private sector prior to divestment.

\section{References}


Corporate Governance Practices in Bangladesh .....http://www.asaub.edu.bd/data/asaubreview/v4n2s119.pdf

Practices of Corporate Governancein Commercial Banks of ...

https://www.slideshare.net/mdsaimonch/practices-of-corporate-governance-in-commercial-banks-of-bangladesh-a-studyon-pubali-bank-ltd

Ajith Nivard Cabraal: Importance of corporate governance ... https://www.bis.org/review/r070314c.pdf

Study Report on Corporate Governance in Bangladesh: How ... http://unpan1.un.org/intradoc/groups/public/documents/apcity/unpan048473.pdf

Bangladesh Bank. (2016). Financial System, Banks \& FIS, (online). Retrieved from https://www.bb.org.bd/fnansys/bankfi.php, on December 15, 2016

Aggarwal, R., \& Yousef, T. (2000). Islamic Banks and Investment Financing. Journal of Money, Credit and Banking, 32 (1), 93-120.

Ahmad, M. F., Hussain, M. S. \& Hannan, S.A. (1999). Experiences in Islamic Banking: A Case Study of Islamic Bank Bangladesh. Dhaka: Institute of Policy Studies

Akkas, A. (1996). Relative Efficiency of the Conventional Banking System in Financing Investment. Ph.D. Dissertation, Dhaka University.

El-Qorchi, M. (2005). Islamic Finance Gears Up. Finance and Development, 42(4), 46-50.

Hassan, M. \& Bashir A. (2003). Determinants of Islamic Banking profitability, Paper presented at the Economic Research Forum (ERF) 10th Annual Conference, Marrakesh, Morocco, 16-18 December

Jaffar, M., \& Manarvi, I. (2011). Performance comparison of Islamic and Conventional banks in Pakistan, Global Journal of Management and Business Research. Vol 11(1), pp 1-7

Merchant, P. (2012). Empirical Study of Islamic Banks Versus Conventional Banks of GCC, Global Journal of Management and Business Research, Volume 12, Issue 20 Version 1.0.

Mohamad, S., Hassan,T. \& Bader, M. (2008). Efficiency of conventional versus Islamic Banks: international evidence using the Stochastic Frontier Approach (SFA), Journal of Islamic Economics, Banking and Finance, 4(2), pp. 107-130

Petersen, M \& Schoeman, I. (2008). Modeling of Banking Profit via Return-on-Assets and Return-on-Equity, Proceedings of the World Congress on Engineering, 2, pp. 1-6

Farmers Bank: More scams coming out http://bangladesh.timesofnews.com/farmers-bank-more-scams-coming-out.html

Afroze, Sadia and Jahan, Mosammet Asma (2005), Corporate Governance Practices in Bangladesh, Dhaka University Journal of Business Studies.

Farmers Bank tagged 'risky' for financial sector | Dhaka ... http://www.dhakatribune.com/business/banks/2017/10/30/farmers-bank-tagged-risky-financial-sector/

Farmers Bank: What we know so far - thedailystar.net http://www.thedailystar.net/frontpage/farmers-bank-more-scams-coming-out-1504675

Farmers Bank unable to return client deposits: Muhith ... http://www.thedailystar.net/country/farmers-bank-unable-to-return-client-deposits-says-finance-minister-ama-muhith-152 5117

Chowdhury, AA Mahboob Uddin : "Role of corporate Governance for the development of Bangladesh Capital Market”, New Nation , 17 may 2006.

Securities and Exchange Commission (2006): “Corporate Governance Notification”, the 20 February ,2006

OECD development Centre Working paper,OECD publishing, "Corporate Governance and National Development"

Adalbert Winkler \& Francesco Mazzaferro \& Carolin Nerlich \& Christian(2004), ” Financial development ,Economic Growth and Corporate Governance" University Frankfuit, Department of Finance.

What Is Corporate Governance and Why Do We Need It? https://www.difc.ae/download_file/1621/6126

SONU, C. H., CHOI, A. AND AHN, H.

Audit Fee Structure, Financial Crisis and Corporate Governance

Sonu, C., Choi, A. and Ahn, H. (2017). Audit Fee Structure, Financial Crisis and Corporate Governance. Korean Accounting Journal, 26(6), pp.161-202.

Gentile, M. J., Karpf, J. D., \& Gumbs, K. D. (2017). Fifteenth Annual Directors Institute on Corporate Governance. NY, NY: Practising Law Institute.

Corporate governance and the financial crisis - OECD www.oecd.org/.../corporategovernanceandthefinancialcrisis.htm

Farmers Bank: A downfall in developing economy - thedailystar.net http://www.thedailystar.net/frontpage/farmers-bank-more-scams-coming-out-1504675

Corporate governance - Wikipedia https://en.wikipedia.org/wiki/Corporate_governance

Corporate Governance after the Financial Crisis - Oxford ... www.oxfordscholarship.com/view/10.1093/acprof:oso/9780199772421...

Corporate Governance after the Financial Crisis - Stephen ... https://global.oup.com/academic/product/corporate-governance-after...

Corporate Governance and the Financial Crisis - Springer https://link.springer.com/content/pdf/10.1057/9781137328878_13.pdf

Short-Termism, the Financial Crisis, and Corporate Governance https://papers.ssrn.com/sol3/papers.cfm?abstract_id=2006556

Corporate Governance in the Wake of the Financial Crisis unctad.org/en/Docs/diaeed20102_en.pdf

Corporate Governance after the Financial Crisis, P. Vasudev-Susan Watson - - 2012

Omega-3 Fatty Acids and/or Multi-domain Intervention in ... https://clinicaltrials.gov/ct2/show/NCT00672685

Brick, I. E., Palmon, O., Wald, J. K., 2006. CEO Compensation, Director Compensation and Firm Performance: Evidence from Cronyism. Journal of Corporate Finance 12, 403-423. 
BEI (2004), "The code of corporate governance for Bangladesh: principles and guidelines for best practices in the private sector, financial institutions, state-owned enterprises and non-governmental organizations", Task Force on Corporate Governance, Bangladesh Enterprise Institute, Dhaka, pp. 1-85.

BSEC Notification (2012), Status of compliance with the conditions imposed by Bangladesh Securities and Exchange Commission's Notification No.SEC/ CMRRCD/2006-158/134/Admin/44 dated 07 August 2012: http://www.secbd.org/Notification\%20on\%20CG-07.8.12-Amended.pdf.

Cheng, S., 2008. Time to Revamp Insider Boards. National Real Estate Investor, 45-72

Chen, C. J., \& Jaggi, B. (2001). Association between independent nonexecutive directors, family control and financial disclosures in Hong Kong. Journal of Accounting and Public policy, 19(4), 285-310.

Coombes, P., \& Watson, M. (2000). Three surveys on corporate governance. McKinsey Quarterly, (4; SPI), 74-77.

Conger, J., Lawler, E. E., 2009. Sharing Leadership on Corporate Boards: A Critical Requirement from Teamwork at the Top. Retrieved from SSRN e-Library: http://ssrn.com/paper=1313353

DeFond, M. L., \& Jiambalvo, J. (1991). Incidence and circumstances of accounting errors. Accounting review, 643-655.

Denis, D. K. and J. J. McConnell (2003), International Corporate Governance, Finance Working Paper \# 05/2003, European Corporate Governance Institute.

Epps, R. W. and Cereola, S. J., 2008. Does institutional shareholder service (ISS) corporate governance rating reflect a company's operating performance? Critical Perspective on Accounting. 1135-1148.

Feizizadeh, A. (2012). Strengthening internal audit effectiveness. Indian Journal of Science and Technology, 5(5), 2777-2778.

Gande, A., John, K., \& Senbet, L. W. (2008). Bank incentives, economic specialization, and financial crises in emerging economies. Journal of International Money and Finance, 27(5), 707-732.

Johnson, R. A., Greening, D. W., 1999. The Effects of Corporate Governance and Institutional Ownership Types of Corporate Social Performance. Academy of Management Journal 42(5), 564-576.

Lipton, M., Lorsch, J.W., 1992. A modest proposal for improved corporate governance. The Business Lawyer 48,59-77, November.

Ondieki, N. M. (2013). Effect Of Internal Audit On Financial Performance Of Commercial Banks In Kenya (Doctoral dissertation, University of Nairobi).

Peasnell, K. V., Pope, P. F., \& Young, S. (2000). Accrual management to meet earnings targets: UK evidence pre-and post-Cadbury. The British Accounting Review, 32(4), 415-445.

Singh, M., Davidson, W. N., 2003. Agency Cists, Ownership Structure and Corporate Governance Mechanisms. Journal of Banking and Finance 27, 793-816.

Abdel Shahid, S. (2001) Corporate Governance is a Global Pursuit: What Could Be Done in Egypt? SSRN Electronic Journal. Available at: http://dx.doi.org/10.2139/ssrn.286875.

Aburime, T.U. (2008). Determinants of bank profitability: macroeconomic evidence from Nigeria. Retrieved from: http://papers.ssrn.com/sol3/papers.cfm?abstract_id=1231064.

Ahmed, S.U. and Uchida S. (2009). Benchmarking the State of Corporate Governance in Bangladesh, KEIEI TO KEIZAI, Vol. 89, No. 3, December 2009.

Ajanthan, A., Balaputhiran, S. \& Balasundaram, N. (2013). Corporate Governance and Banking Performance: A Comparative Study between Private and State Banking Sector in Sri Lanka. European Journal of Business and Management, 5 (No. 20), p. 92.

Alpera, D. \& Anbar, A. (2011). Bank Specific and Macroeconomic Determinants of Commercial Bank Profitability: Empirical Evidence from Turkey, Business and Economics Research Journal, 2 (2).

Alshatti, Ali Sulieman. (2015) The effect of credit risk management on financial performance of the Jordanian commercial banks, Investment Management and Financial Innovations, Volume 12, Issue 1, pp. 338-345.

Athanasoglou, P.P., Delis, M.D. \& Staikouras, C.K. (2006). Determinants of Bank Profitability in the South Eastern European Region. Munich Personal RePEc Archive.

Samuelson, P.A. (1945). The Effect of Interest Rate Increases on the Banking System, American Economic Review, 305, pp. 16-27.

Sayilgan, G. \& Yildirim, O. (2009). Determinants of Profitability in Turkish Banking Sector: 2002-2007, International Research Journal of Finance and Economics, 28, pp. 207-213

Smirlock, M. (1985). Evidence on the (Non) Relationship between concentration and profitability in Banking, Journal of Money Credit and Banking, 17, pp. 69-83.

Staikouras, C. \& Wood, G. (2003). The determinants of bank profitability in Europe. Paper presented at the European Applied Business Research conference.

Sufian, F. \& Habibullah, M.S. (2010). Assessing the impact of financial crisis on bank Performance, empirical evidence from Indonesia, ASEAN Economic Bulletin, 27, pp. 245-262.

Wheelen, T.L. \& Hunger, J. (2006). Strategic Management and Business Policy. United States of America: Pearson Prentice Hall. Available at: http://www.kvimis.co.in/sites/kvimis.co.in/files/ebook_attachments/Thomas $\%$ 20L.\%20Wheelen,\%20Strategic\%20Management.pdf 